\section{Ultrastructural Characterization of Yellow Shoulder Disorder in a Uniform Ripening Tomato Genotype}

\author{
David M. Francis ${ }^{1}$ \\ Department of Horticulture and Crop Science, Ohio Agricultural Research \\ and Development Center, 1680 Madison Avenue, Wooster, OH 44691-4096
}

Sheryl A. Barringer

Department of Food Science and Technology, The Ohio State University, Columbus, OH 43221

Robert E. Whitmoyer

Molecular and Cellular Imaging Center, Ohio Agricultural Research and Development Center, 1680 Madison Avenue, Wooster, OH 44691-4096

Additional index words. Lycopersicon esculentum, fruit, color, plastid, chromoplast, development, histology

\begin{abstract}
Yellow shoulder disorder (YSD) is characterized by sectors of yellow or green tissue under the peel of uniform ripening tomato (Lycopersicon esculentum Mill.) fruit. Tissues excised from sectors of fruit expressing YSD, from adjacent red sectors, and from mature green fruit were used to compare the ultrastructural alterations in cells and tissue affected by YSD and to determine whether the disorder is caused by delayed fruit maturation or by aberrant development. Cells from YSD sectors were smaller than those from both adjacent red-ripe tissue and mature green fruit. The smaller cells from the YSD sectors were at a different developmental stage than cells of the adjacent red-ripe tissue. Chromoplasts in red-ripe tissue were more advanced in development than those in YSD sectors or mature green fruit. Using the transition from chloroplast to chromoplast and the degradation of the middle lamella between adjacent cells as developmental markers, the maturity of tissue from YSD sectors appeared to be equal or greater than that of tissue from mature green fruit. However, cell enlargement, which takes place early in fruit development, was retarded in YSD sectors. Therefore, the ultrastructural features of YSD are not compatible with a delayed ripening model for this blotchy ripening disorder. These observations provide a basis for comparing YSD in uniformly ripening tomatoes with other blotchy ripening disorders.
\end{abstract}

Several classification schemes have been proposed for blotchy ripening disorders (Bewly and White, 1926; Cooper, 1958; Sadik and Minges, 1966), but these schemes predate the widespread utilization of determinate $(\mathrm{sp} / \mathrm{sp})$ uniform ripening $(\mathrm{u} / \mathrm{u})$ cultivars (Ayers and Tomes, 1966). Discolored regions under the fruit epidermis (Schlimme et al., 1984) characterize yellow shoulder disorder (YSD). This disorder is the most common cause of withinfruit color variation found in the genotypes of tomatoes grown for processing in the midwestern and eastern United States and in

Received for publication 4 Aug. 1999. Accepted for publication 7 Dec. 1999. Salaries and research support were provided by state and federal funds appropriated to The Ohio State Univ., Ohio Agricultural Research and Development Center, and grant funds by the Mid-America Food Processors Association. We would like to acknowledge the technical assistance of Barb Franchino. The cost of publishing this paper was defrayed in part by the payment of page charges. Under postal regulations, this paper therefore must be hereby marked advertisement solely to indicate this fact.

${ }^{1}$ To whom reprint requests should be addressed. E-mail address: francis.77@ osu.edu
Ontario, Canada (Corey et al., 1986; Francis, unpublished observations). A notable characteristic of YSD is that it is often restricted to the flesh below the peel. Ripe fruit appear red and normal until the peel is removed by steam, lye, or cutting to reveal bands of yellow or green in the parenchyma tissue. Yellow shoulder disorder may be related to a disorder characterized by an external yellow ring around the abscission zone and internal white tissue (IWT), as described by Sadik and Minges (1966). Recently, Hartz et al. (1999) referred to a yellow ring around the abscission zone on uniform ripening processing tomatoes from California as yellow shoulder (YS). Picha (1987) defined YS as a disorder characterized by sectors of yellow or yellow-orange tissue separated from normal red tissue by a clear demarcation. His definition is based on the expression of blotchy ripening in nonuniform ripening genotypes $(\mathrm{u}+/ \mathrm{u}+)$ of fresh-market tomatoes. The apparent contrast between disorders with visible external symptoms such as YS and YSD may be indicative of separate disorders, a difference in expression of the disorder due to plant genotype and growing environment, or simply a reflection of the severity and location of affected internal tis- sue. For example, Sadik and Minges (1966) suggested that the location of internal white tissue affects the expression of external symptoms. The physiological, genetic, and ultrastructural relation between YSD and other blotchy ripening disorders has not been studied.

Yellow shoulder disorder is both economically important and biologically interesting. Standards for grading of processed vegetables set strict limits on the amount of discolored tissue in peeled tomato products. Yet grading practices rarely detect YSD prior to peeling. Thus, premium prices may be paid for tomatoes that do not yield an acceptable percentage of high-grade fruit after processing. In addition, the tomato peel adheres to the subtending discolored flesh after peeling, reducing processing efficiency (Schlimme et al., 1984). Blotchy ripening disorders are often described as delayed ripening phenomena, with the cells of affected tissue retaining immature characteristics (Bewly and White, 1926). Considerable physiological evidence suggests that most blotchy ripening disorders involve aberrant ripening (Davies, 1966; Winsor et al., 1962). The expression and severity of blotchy ripening disorders is influenced by nutritional, meteorological, and pathological factors (Hanif-Khan et al., 1998; Hobson and Davies, 1976; Jones and Alexander, 1962; Picha and Hall, 1981). In addition, the severity of YSD appears to have a genetic component (Corey et al., 1986; Fogleman, 1966; Hartz et al., 1999; Sacks and Francis, unpublished results), and genetic approaches may be useful in separating the physiological and developmental alterations responsible for YSD.

The objectives of this research were to characterize the ultrastrucural alterations in tissue from sectors with YSD and to determine whether YSD is caused by delayed fruit maturation or by aberrant development. The results described below make possible a comparison of YSD in uniform ripening processing tomatoes with other blotchy ripening disorders. We suggest that altered development is a more appropriate model than delayed ripening for describing YSD.

\section{Materials and Methods}

Plant material. Ripe fruit from field-grown tomatoes were harvested from The Ohio State Univ.'s Vegetable Crops Branch in Fremont, Ohio, and from the Horticulture Farm in Wooster, Ohio. Production practices were as recommended for commercial growers (Precheur, 1997). Fruit from an inbred cultivar, 'Ohio 8245' (Berry et al., 1991), grown in Fremont, were used for all cytological and ultrastructural analysis.

Fruit from 36 uniform ripening cultivars and breeding lines were used to test the coincidence of YSD and the presence of a visible external yellow ring as described by Sadik and Minges (1966) and Hartzet al. (1999). Twentyfour fruit from each plot were cut across the abscission zone to remove the peel and the presence of YSD was noted. In addition, objective color data were collected by using a 


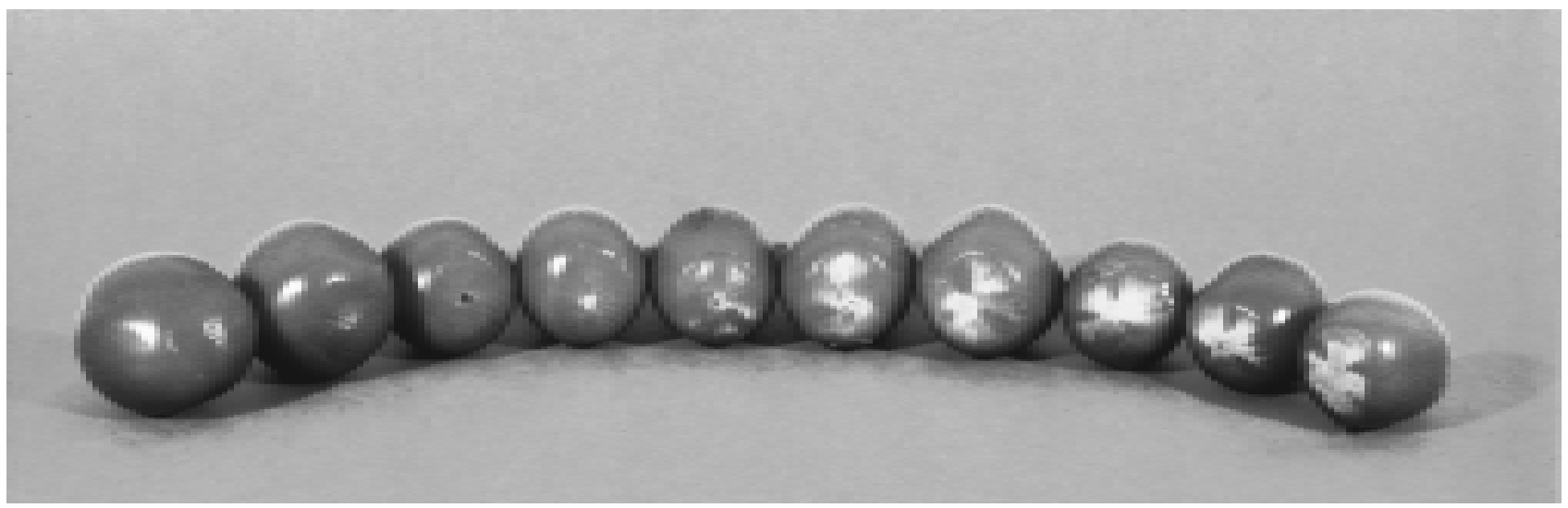

Fig. 1. The range of fruit obtained from cv. Ohio 8245 grown in Fremont, Ohio. Fruit were cut across the abscission zone to remove the peel and reveal sectors associated with vacuolar tissue along the inter-locule wall. Fruit not affected are to the left and severely affected fruit to the right.

Minolta CR 300 colorimeter (Minolta Co., Ramsey, N.J.). Results from the analysis of these objective data for the 36 genotypes grown in a multi-year replicated trial will be reported elsewhere.

Tissue preparation. Blocks of tissue (3-4 $\mathrm{mm}^{2}$ ) were excised from three mature-green fruit and from three red-ripe fruit with YSD. For the fruit with YSD, tissue was prepared from both red and YSD sectors. Blocks of tissue from these nine specimens were processed as independent samples throughout the course of these experiments. Specimens were fixed in a solution of $3 \%$ glutaraldehyde, $2 \%$ paraformaldehyde, and $1.5 \%$ acrolein in a 0.1 M collidine buffer at $\mathrm{pH} 7.3$ for $30 \mathrm{~min}$ at room temperature followed by $12 \mathrm{~h}$ at $4{ }^{\circ} \mathrm{C}$. The specimens were washed with $0.1 \mathrm{M}$ phosphate buffer ( $\mathrm{pH} 7.4$ ) and post-fixed in $2 \%$ osmium tetroxide in the same buffer for $3 \mathrm{~h}$. Tissue was further washed and stained in $1 \%$ uranyl acetate ( $0.1 \mathrm{~m}$ phosphate buffer, $\mathrm{pH} 7.4)$ overnight. The specimens were dehydrated in an ethanol-acetone series, embedded in Spurr plastic (Ladd Research Industries, Burlington, Vt.), and the plastic was polymerized at $70{ }^{\circ} \mathrm{C}$ (Spurr, 1969). Blocks were sectioned on a Sorvall MT-2B Ultramicrotome (Du Pont Co., Wilmington, Del.) using glass knives prior to trimming. Trimmed blocks were sectioned using a diamond knife, and sections were picked up on Formvar-coated grids.

Microscopy. Tissue sections were cut from blocks using glass knives, and stained with $0.2 \%$ toluidine blue in $0.1 \%$ sodium carbonate prior to viewing with a Zeiss Model WL light microscope (Carl Zeiss, Thornwood, N.Y.). Sections were photographed with a Leaf Microlumina digital camera (Leaf Systems, Bedford, Mass.). Light microscope images were used to select areas of the blocks for trimming and thin sectioning. Thin sections were viewed and photographed using a Philips 201C Electron Microscope (Philips, Eindhoven, Germany).

Digital images and photographs of 12 to 47 representative cells for each tissue type were used for subsequent measurements. Light microscope sections were used for measurements of cell width and length. Photographs from the electron microscope were used to measure cell wall thickness and presence or absence of plasmodesmata, chloroplasts, a middle lamella, and vacuoles. In addition, descriptions of chloroplasts and chromoplasts in tomato fruit (Bathgate et al., 1985; Ljubesic et al., 1991) and the developmental changes described by Khudairi (1992) were used for a subjective scale of chloroplast conversion into chromoplasts. Plastids showing organized and stacked grana characteristic of chloroplasts were given a rating of 1 . Plastids with grana, but less highly organized, were rated 2 , corresponding to the transition stage noted by Khudairi. Plastids lacking grana were rated 3, corresponding to developing chromoplasts. Mature chromoplasts characterized by lycopene bodies were rated 4 , and chromoplasts that showed signs of necrosis were rated 5 .

Statistics. All statistical analysis were performed using SAS release 6.12 (SAS Institute, Cary, N.C.). Measurements of cell length, cell width, and cell wall thickness were analyzed using analysis of variance with the general linear models (GLM) procedure. Scaled data were analyzed with the Kruskal-Wallis test for differences using the nonparametric one-way procedure. A chi-square test was used to detect differences between the presence and absence of chloroplasts, middle lamella, and vacuoles in each of the three tissue types.

\section{Results and Discussion}

A higher incidence of YSD was observed in fruit from the Fremont location relative to the Wooster location $(P \leq 0.01)$. Of the 36 varieties and breeding lines, 'Ohio 8245 ' was among the most severely affected by YSD. In contrast, 'Ohio 8556' was significantly less affected by YSD $(P \leq 0.05)$. These results are consistent with the results of Hartz et al. (1999). Figure 1 shows the range in appearance of fruit obtained from 'Ohio 8245' at the Fremont location. The green or yellow sectors were usually associated with vascular tissue along the inter-locule wall. All fruit of the 36 varieties and breeding lines with a yellow ring $>2$ $\mathrm{mm}$ around the abscission zone displayed internal symptoms of YSD. However, only 15\% of fruit with YSD had a visible yellow ring. Yellow shoulder disorder, characterized by internal symptoms, and YS, characterized by external symptoms, may have a common cause, and the expression of visible external symptoms may reflect the position and amount of IWT as suggested by Sadik and Minges (1966). Hartz et al. (1999) report a high correlation between YS and IWT. Our observations and these reports are consistent with YSD, YS, and IWT being related disorders, but further investigation is required to establish the relationship.

Table 1. Ultrastructural features of cells from 'Ohio 8245' mature-green fruit, red-ripe tissue of fruit with YSD, and discolored tissue of fruit with YSD.

\begin{tabular}{|c|c|c|c|c|c|c|}
\hline & \multicolumn{6}{|c|}{ Tissue type } \\
\hline & $\begin{array}{l}\text { Mature- } \\
\text { green }\end{array}$ & $\begin{array}{c}\text { No. of } \\
\text { samples }\end{array}$ & $\begin{array}{l}\text { Red- } \\
\text { ripe }\end{array}$ & $\begin{array}{c}\text { No. of } \\
\text { samples }\end{array}$ & $\begin{array}{l}\text { Yellow } \\
\text { shoulder }\end{array}$ & $\begin{array}{c}\text { No. of } \\
\text { samples }\end{array}$ \\
\hline Cell width (mm) & $0.328 \mathrm{a}^{\mathrm{z}}$ & 38 & $0.368 \mathrm{a}$ & 39 & $0.251 \mathrm{~b}$ & 70 \\
\hline Cell length (mm) & $0.592 \mathrm{a}$ & 38 & $0.499 \mathrm{~b}$ & 39 & $0.365 \mathrm{c}$ & 70 \\
\hline Cell wall thickness (u) & $1.61 \mathrm{a}$ & 18 & $1.62 \mathrm{a}$ & 12 & $\begin{array}{l}1.62 \mathrm{a} \\
(0.85 \mathrm{~b})^{\mathrm{y}}\end{array}$ & $\begin{array}{l}13 \\
32\end{array}$ \\
\hline $\begin{array}{l}\text { Cells with middle } \\
\text { lamella }(\%)\end{array}$ & 77.78 & 18 & $0.0^{*}$ & 12 & $\begin{array}{c}46.15 \\
(65.63)\end{array}$ & $\begin{array}{l}13 \\
32\end{array}$ \\
\hline Cells with vacuoles $(\%)$ & 100 & 15 & 85.71 & 14 & $\begin{array}{l}100 \\
(76.92)\end{array}$ & $\begin{array}{l}23 \\
39\end{array}$ \\
\hline Chloroplast stage & 2.0 & 12 & $4.56^{* *}$ & 35 & 2.45 & 47 \\
\hline
\end{tabular}

${ }^{\mathrm{z}}$ Mean separations were performed after a significant ANOVA using a two-tailed $t$ test. Means followed by the same letter are not significantly different.

${ }^{y}$ Data are presented with sample three omitted from the analysis, and (in parenthesis) included in the analysis. *,** Significant at $P \leq 0.01$, based on a chi-square test, and at $P \leq 0.001$, based on a Kruskal-Wallis test, respectively. 


\section{Postharvest Biology \& Technology}

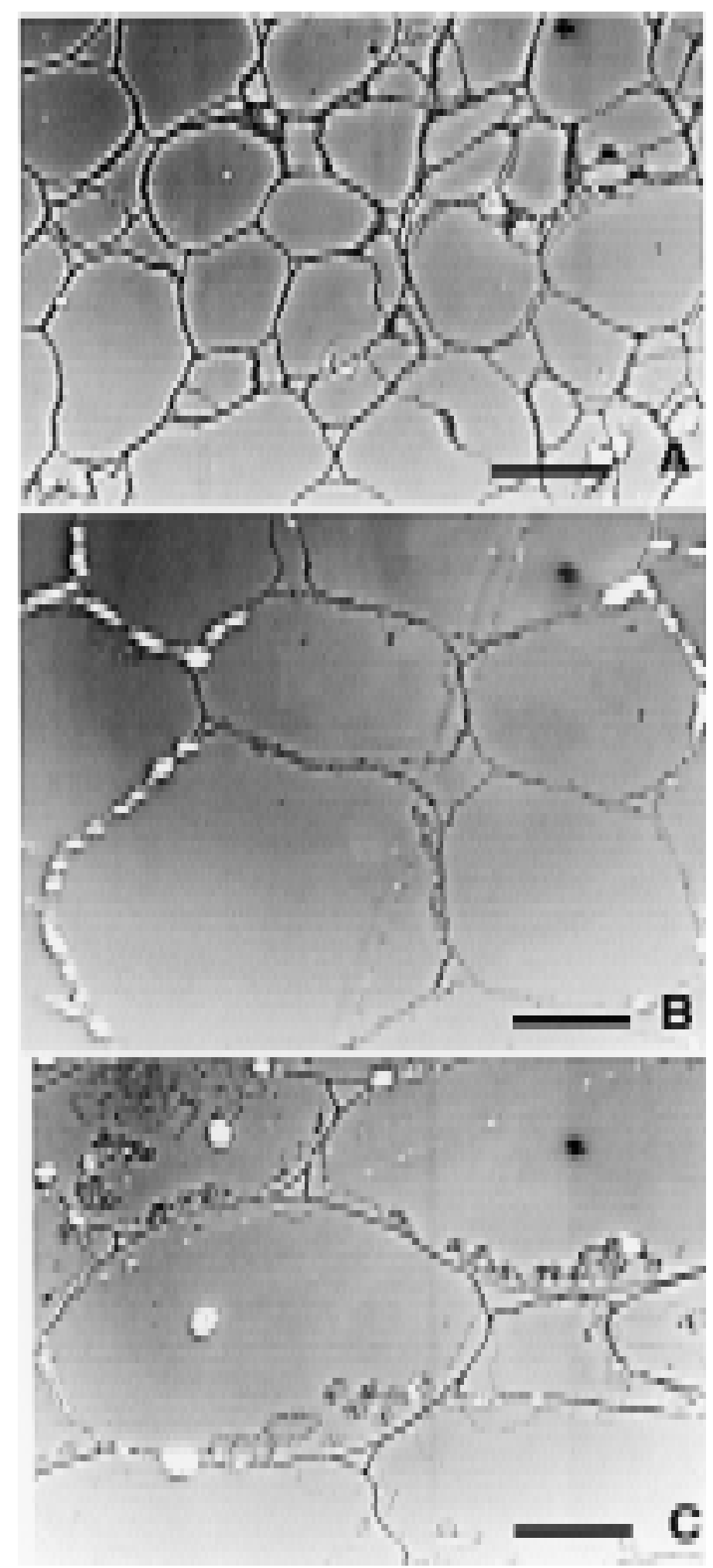

Fig. 2. Light micrographs (bar $=0.2 \mathrm{~mm}$ ) showing representative cell sizes found in tissue affected by (A) yellow shoulder disorder, (B) adjacent red-ripe tissue from the same fruit, and (C) tissue from mature-green fruit . All samples are from cv. Ohio 8245.

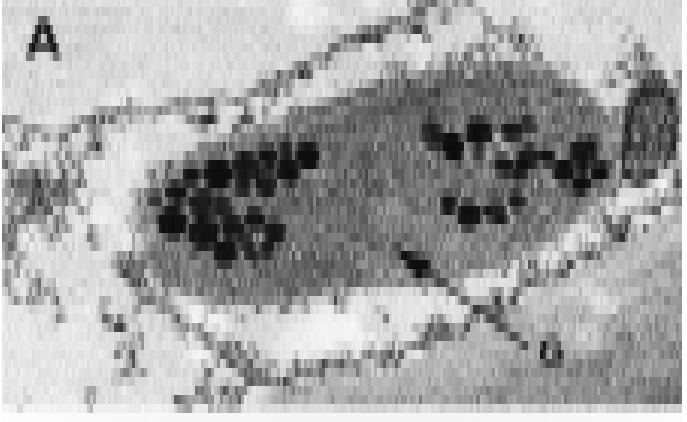

B
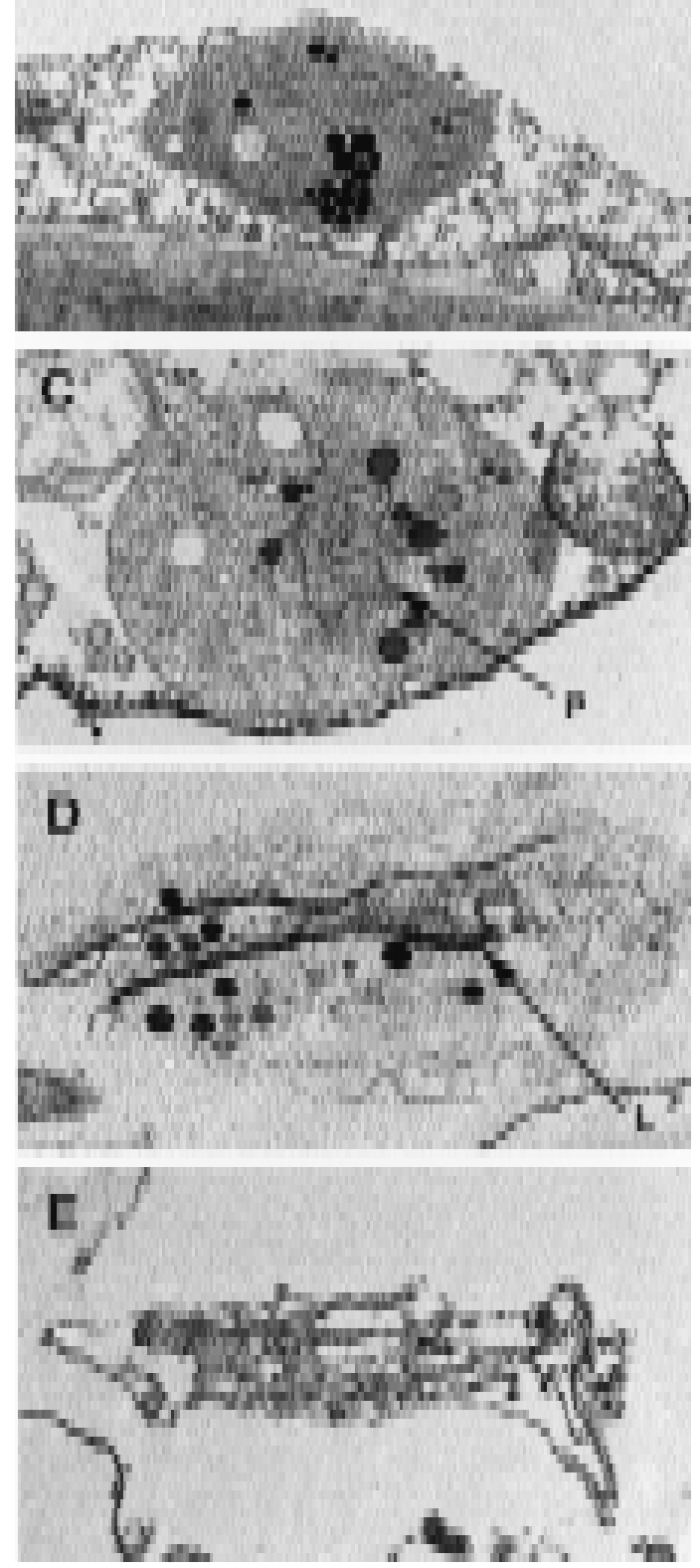

Fig. 3. Five stages of chromoplast development (A to E) used as developmental markers. Plastids showing organized and stacked grana $(\mathbf{G})$ characteristic of chloroplasts were given a rating of 1 (panel $\mathbf{A}$ ); plastids with grana, but less highly organized were rated 2 and corresponded to the chloroplast-chromoplast transition stage (panel B); plastids lacking grana and containing developing lycopene bodies $(\mathbf{P})$ were rated 3 and correspond to developing chromoplasts $(\mathbf{C})$; mature chromoplasts characterized by lycopene bodies (L) were rated $4(\mathbf{D})$; and chromoplasts that showed signs of necrosis were rated $5(\mathbf{E})$. 
Tissue was prepared from three maturegreen and three ripe fruit with YSD for cytological and ultrastructural analysis. Blocks of tissue from red-ripe and YSD sectors were derived from the same fruit. Multiple measurements and observations were made for each fruit using photographs and digital images. No within-tissue variation was observed for tissue from mature-green fruit or red sectors in YSD fruit (data not shown), but significant variation was observed within tissue from YSD sectors for cell wall thickness, the presence of a middle lamella, and the presence of a vacuole. Cells from the YSD sector from fruit number 3 differed significantly from YSD samples from fruit 1 and 2 for cell wall thickness, the presence of a middle lamella, and the presence of vacuoles. Many of the cells in tissue sample 3 were small nucleated cells that lacked chloroplasts and vacuoles. This morphology contrasted with that of the chloroplast rich vacuolated cells characteristic of parenchyma in all other samples we examined. These cells may have been vascular companion cells, though no vascular elements were observed. The lack of chloroplasts and associated pigments in sample 3 may be responsible for the IWT often associated with color disorders (Sadik and Minges, 1966). Analysis of between tissue type differences were performed with and without data collected from YSD sample 3 (Table 1).

Cells from YSD tissue were noticeably smaller than the cells of either adjacent redripe tissue or of mature-green fruit (Fig. 2). The widths and lengths of cells from YSD tissue were smaller $(P \leq 0.0001)$ than cells from both red-ripe and mature-green tissue (Table 1). In addition, the lengths of cells from red-ripe tissue were less $(P \leq 0.05)$ than cells from mature green tissue (Table 1$)$. This variation may reflect differences in the position of the fruit on the plant (crown set vs. tertiary set), the plane of sectioning through the cell, or maturity. A difference in the size of cells was previously noted for fruit with a blotchy ripening disorder called "green back" (Bewly and White, 1926) and in histological studies of blotchy selections by Fogleman (1966). Finally, the cells found in YSD tissue tend to be more randomly organized than those in redripe and mature-green tissue (Fig. 2). Such disorganization was noted in the histological studies of Sadik and Minges (1966).

The smaller cells from the YSD sectors appear to be at a different developmental stage than cells of the adjacent red-ripe tissue. Representative plastids (Fig. 3) demonstrate the developmental changes that accompany conversion from chloroplast to chromoplast in ripening fruit. The chloroplasts from cells of mature-green tissue were beginning to undergo a conversion to chromoplasts, as indicated by the average stage rating of 2.0 (Table
1). In contrast, cells from red-ripe tissue had plastids that were significantly further along in chromoplast development $(P \leq 0.0001)$, averaging 4.56 on the scale. Plastids from YSD tissue averaged 2.45 and were significantly different from those in red-ripe tissue $(P \leq$ 0.0001 ), but not in mature-green tissue (Table 1).

Red-ripe tissue also differed from mature green tissue and YSD tissue in the notable absence of any middle lamella between adjacent cells (Table 1). This result reflects the decomposition of pectic substances during the ripening process. Tissue types did not differ significantly for the thickness of cell walls or the presence of vacuoles (Table 1), plasmodesmata, and chloroplasts (data not shown) when YSD tissue sample 3 was omitted from the analysis. As indicated above, YSD tissue from sample 3 was different from the other YSD samples with respect to cell wall thickness and the presence of a middle lamella and a vacuole. Including this sample in the analysis of differences between tissue types affected the significance of the cell wall thickness measurements but not the other analyses (Table 1).

Our results indicate that the ultrastructural features of YSD are not compatible with a delayed ripening model for this blotchy ripening disorder. Using chromoplasts and the presence of a middle lamella between adjacent cells as developmental markers, the maturity of YSD tissue appears to be comparable with that of tissue from mature-green fruit. However, cell expansion is thought to be complete by the mature-green fruit stage (Esau, 1977; Fogleman, 1966). Therefore, YSD apparently affects cell enlargement early in fruit development since cells from YSD sectors were smaller than those from mature-green fruit. These results are compatible with the findings of Sadik and Minges (1966), who observed disorganization of parenchyma cells and the deposition of a lignin-like material in the intercellular spaces in immature-green fruit at the early stages of certain color disorders. Chemical analysis of fruit with blotchy ripening disorders also suggests that blotchy fruit are not merely delayed, but are altered in development (Davies, 1966; Winsor et al., 1962). It is more appropriate to consider YSD to involve modified development rather than delayed development.

\section{Literature Cited}

Ayers, J.E. and M.L. Tomes. 1966. The effect of two uniform ripening genes on chlorophyll and carotenoid contents of tomato fruit. J. Amer. Soc. Hort. Sci. 88:550-556.

Bathgate, B., M.E. Purton, D. Grierson, and P.W Goodenough. 1985. Plastid changes during the conversion of chloroplasts to chromoplasts in ripening tomatoes. Planta 165:197-204.

Berry, S.Z., W.A. Gould, and K.L. Wiese. 1991.
'Ohio 8245 ' processing tomato. HortScience 26:1093.

Bewly, W.F. and H.L. White. 1926. Some nutritional disorders of the tomato. Ann. Biol. 13:233328.

Cooper, A.J. 1958. The definition and classification of abnormalities of fruit pigmentation in the tomato variety 'Potentate'. Ann. Appl. Biol. 46:669-674.

Corey, K.A., D.V. Schlimme, and B.C. Frey. 1986. Peel removal by high pressure steam from processing tomatoes with yellow shoulder disorder. J. Food Sci. 51:388-390.

Davies, J.N. 1966. The non-volatile organic acids of the differently coloured area of the walls of 'blotchy' ripened tomatoes. J. Sci. Food Agr. 17:400-403.

Esau, K. 1977. Anatomy of seed plants. $2^{\text {nd }}$ ed. Wiley, New York.

Fogleman, M.E. 1966. A genetic and histological study of blotchy ripening in segregating generations of a tomato cross. PhD Diss., Iowa State Univ., Ames (Book No. SB349 F689g. Accession No. T18108).

Hanif-Khan, S., R.C. Bullock, P.J. Stoffella, C.A. Powell, J.K. Brecht, H.J. McAuslane, and R.K. Yokomi. 1998. Tomato irregular-ripening symptom development and ripening of silverleaf whitefly-infested dwarf cherry tomatoes. J. Amer. Soc. Hort. Sci. 123:119-125.

Hartz, T.K., G. Miyao, R.J. Mullen, M.D. Cahn, J. Valencia, and K.L. Brittan. 1999. Potassium requirements for maximum yield and fruit quality of processing tomato. J. Amer. Soc. Hort. Sci. 124:199-204.

Hobson, G.E. and J.N. Davies. 1976. A review of blotchy ripening and allied disorders of the tomato 1957-1976. Glasshouse Crops Res. Instit. Annu. Rpt. 1976.139-147.

Jones, J.P. and L.J. Alexander. 1962. Relation of certain environmental factors and tobacco mosaic virus to blotchy ripening of tomatoes. Phytopathology 52:524-528.

Khudairi, A.K. 1992. The ripening of tomatoes. Amer. Sci. 60:696-707.

Ljubesic, N., M. Wrischer, and Z. Devide. 1991. Chromoplasts- the last stages in plastid development. Intl. J. Dev. Biol. 35:251-258.

Picha, D.H. 1987. Physiological factors associated with yellow shoulder expression in tomato fruit. J. Amer. Soc. Hort. Sci. 112:798-801.

Picha, D.H. and C.B. Hall. 1981. Influences of potassium, cultivar, and season on tomato graywall and blotchy ripening. J. Amer. Soc. Hort. Sci. 106:704-708.

Precheur, R.J. 1997. Ohio Vegetable Production Guide. Ohio State Univ. Coop. Ext. Bul. No. 672.

Sadik, S. and P.A. Minges. 1966. Symptoms and histology of tomato fruits affected by blotchy ripening. J. Amer. Soc. Hort. Sci. 88: 532-543.

Schlimme, D.V., K.A. Corey, and B.C. Frey. 1984. Evaluation of lye and steam peeling using four processing tomato cultivars. J. Food Sci. 49:1415-1418.

Spurr, A.R. 1969. A low viscosity epoxy resin embedding medium for electron microscopy. J. Ultrastruct. Res. 26:31-43.

Winsor, G.W., J.N. Davies, and D.M. Massey. 1962. Composition of tomato fruit. V. Comparison of the differently coloured areas of the walls of 'blotchy' tomatoes. J. Sci. Food. Agr. 13:145-148. 